\title{
HYDROPS FOETALIS SUCCESSFULLY TREATED BY EXCHANGE TRANSFUSION
}

\author{
BY \\ JOSEPHINE COOK \\ From the Children's Department, St. Bartholomew's Hospital, London
}

(RECEIVED FOR PUBlication JANUARY 5, 1956)

Cases of Rhesus incompatibility resulting in the condition known as hydrops foetalis do badly. Mollison and Cutbush (1954) state 'it is doubtful if infants born with ascites ever survive', and it is difficult to find any record of survival. Heilig, Tudor, Smith and Platou (1948) report two cases of hydrops, one of which survived with a hemiplegia. Van Loghem, van Bolhuis, Soeters and Veeneklaas (1949) describe, among 160 cases of erythroblastosis foetalis treated with exchange transfusion, four infants with hydrops. Three of these died but the fourth survived. This child, however, had no ascites, only oedema of the umbilical cord, hands and feet. The following case is probably unusual, but worth reporting because of the initial hopeless prognosis and the ensuing remarkable recovery.

\section{Case Report}

The mother was aged 35 years and had had three previous pregnancies. She had a normal child in 1947, and in 1950 was delivered of a stillborn child at the eighth month: unfortunately there are no details available about the stillbirth. A third child was born at full term in 1952. She was known to have group $\mathrm{O}$ Rh-negative blood, and during her third pregnancy in 1952 antibodies were found in the blood at 20 weeks, and subsequently at the thirtieth and thirty-fifth weeks, when the anti-D antibody was present to a titre of 1 in 16 . The father's blood was examined at this time and found to be group $O$ homozygous $\mathrm{Rh}$ positive. The third child was born at term and was noticed to be slightly jaundiced soon after birth. The jaundice deepened within the first hour and cord blood had a positive Coombs test and a haemoglobin content of $92 \%$ Haldane two hours after birth, when $500 \mathrm{ml}$. of group $\mathrm{O} \mathbf{R h}$-negative packed red cells were given. This child is now 3 years old and seems normal in every way.

In 1955 the mother again became pregnant. Rhesus antibodies were present in her blood at 22 weeks and at 32 weeks. At 34 weeks albumin agglutinating anti-D was present to a titre of 1 in 16 , and at 37 weeks to a titre of 1 in 32 . On the second occasion a trace of saline anti-D was also present.
On June 16, 1955, spontaneous delivery complicated by delay in the second stage took place. The delay was found to be due to impaction of the child's ascitic abdomen in the vagina of the mother. The child was a girl weighing $9 \mathrm{lb}$. $2 \frac{1}{2} \mathrm{oz}$. There was no cyanosis or jaundice, but the child was pale with oedema of the feet, legs and vulva, and a large protruding abdomen measuring 18 in. at the widest part. The abdominal wall was so tense that the liver and spleen could not be felt. The heart sounds were present and there were no murmurs. There were medium râles all over both lung fields. The Coombs test was positive on the cord blood, which was group $\mathrm{O} R \mathrm{Rh}$-positive and had a haemoglobin content of $68 \%$ Haldane.

In spite of the child's discouraging appearance, exchange transfusion with packed group $O R h$-negative cells was begun, one hour after birth. It was attempted by the umbilical route, but after much technical difficulty, almost certainly due to the stretching of the umbilical vein by the ascites, this had to be abandoned after only $66 \mathrm{ml}$. of packed cells had been given and $55 \mathrm{ml}$. of blood removed. Eventually exchange transfusion was carried out by cutting down on the left saphenous vein at its point of entry into the femoral vein. In all $442 \mathrm{ml}$. of packed cells were given, and $432 \mathrm{ml}$. of blood removed. Of this, $60 \mathrm{ml}$. were removed at the end of the exchange as an emergency measure because the child became cyanosed and distressed, although continuous oxygen was being given by nasal catheter. By the end of transfusion the moist sounds had completely disappeared from the chest but the respiratory excursion was still very small because of the ascites. Transfusion was not completed until about 10 hours after birth.

The following day the child's general condition was fairly good and the chest was clear, but the legs and thighs were more oedematous than at birth and there was slight jaundice. The abdomen was less tense, measuring 17 in., and both the liver and spleen could now be felt. The liver was enlarged to two fingerbreadths, and the spleen to three, below the costal margin. Haemoglobin was $90 \%$ Haldane, direct Coombs test negative, serum bilirubin $3.8 \mathrm{mg}$. and serum proteins $5 \mathrm{~g}$. per $100 \mathrm{ml}$. (albumin $3.6 \mathrm{~g}$. and globulin $1.4 \mathrm{~g}$.). Intramuscular terramycin was given for four days as a prophylaxis against any infection that might have been introduced at the time of transfusion. Feeding was attempted on 


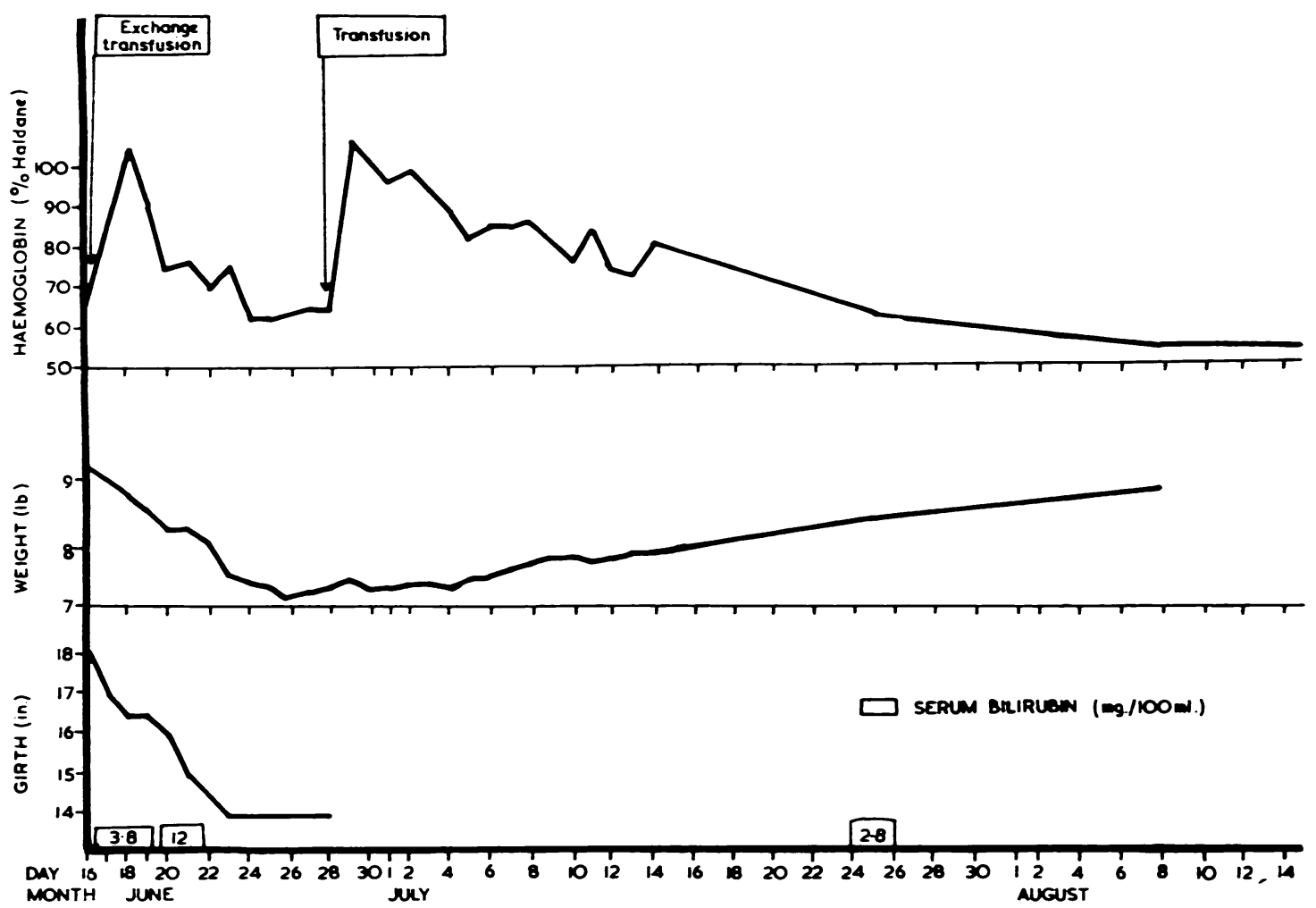

Fig. 1.

the second day and by the third day she was taking small amounts of milk and water fairly well.

The ascites slowly disappeared. The daily measurement of the child's girth and the daily haemoglobin estimations and weights are given in the figure. By about the seventh day the jaundice reached its maximum (approximate maximum total serum bilirubin $12 \mathrm{mg}$. per $100 \mathrm{ml}$.), and then faded gradually. On the ninth day the ascites had disappeared. By the thirteenth day the liver was a little smaller and the spleen definitely smaller, being only 1 in. below the costal margin, but the haemoglobin had fallen to $66 \%$. Because of the increasing anaemia, $105 \mathrm{ml}$. of group $\mathrm{O} \mathrm{Rh}$-negative compatible blood were transfused through a scalp vein. After this, haemoglobin rose to $106 \%$ and gradually dropped again without any further increase in jaundice. On the thirtieth day when the child was discharged home the haemoglobin had fallen to $82 \%$. At this time she was well and looked normal apart from some green staining of the optic sclerae. The spleen was now $\frac{1}{2}$ in. below the costal margin and the liver $1 \frac{1}{2}$ in. below.

The child has been seen several times as an out-patient and is doing well. When she was last seen on October 3,
1955 , at the age of $3 \frac{1}{2}$ months, the spleen was just palpable and the liver was only $\frac{1}{2}$ in. below the costal margin: haemoglobin was $74 \%$ and there was no jaundice. Her weight was $9 \mathrm{lb} .13 \mathrm{oz}$. There have never been any signs or symptoms of kernikterus.

\section{Summary}

A case of hydrops foetalis with gross ascites which did well after exchange transfusion is described. Although the child was in severe heart failure at birth, the degree of anaemia was not so great as is usually found in these cases. This fact may partially account for the recovery.

I should like to thank Dr. Charles Harris for permission to publish this case.

\section{References}

Heilig, W. R., Tudor, R. B., Smith, T. and Platou, E. S. (1948). Journal-Lancet, CS, $222^{2}$

Loghem, J. J. van, Bolhuis, J. H. van, Soeters, J. M. and Veeneklaas, G. M. H. (1949). Brit. med. J., 2, 49.

Mollison, P. L. and Cutbush, Marie (1954). In Recent Advances in Paediatrics, ed. D. Gairdner, p. 110. London. 